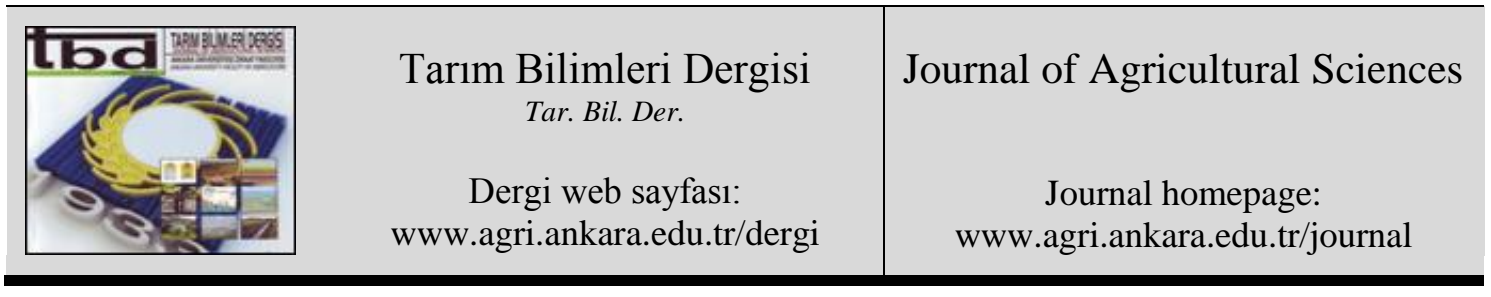

\title{
Alleviation of Toxic Effects of Untreated Wastewater on Selective Vegetables Using Soil Organic Amendments
}

\author{
Zaffar MALIK ${ }^{a}$, Ghulam Hassan ABBASI ${ }^{a}$, Sardar Alam CHEEMA ${ }^{\text {, }}$, Muhammad DAWOOD ${ }^{\text {, }}$ \\ Muhammad Babar JAVED ${ }^{a}$, Muhammad RAFAY ${ }^{\mathrm{e}}$, Malik Noman MANSHA ${ }^{\mathrm{a}}$, Muhammad Imran \\ KHAN ${ }^{\mathrm{c}}$ \\ ${ }^{a}$ Department of Soil Science, University College of Agriculture and Environmental Sciences, Baghdad-ul-Jadeed Campus, The Islamia \\ University of Bahawalpur (63100), PAKISTAN \\ ${ }^{b}$ Department of Agronomy, University of Agriculture Faisalabad (38040), PAKISTAN

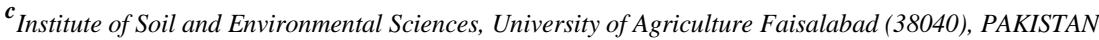 \\ ${ }^{d}$ Department of Environmental Sciences, Bahauddin Zakariya University, Multan, PAKISTAN \\ ${ }^{\boldsymbol{e}}$ Department of Forestry, University College of Agriculture and Environmental Sciences, Baghdad-ul-Jadeed Campus, The Islamia University \\ of Bahawalpur, PAKISTAN
}

\section{ARTICLE INFO}

Research Article

Corresponding Author: Muhammad Imran KHAN, E-mail: khanimran1173@yahoo.com, Tel: +92 (41) 9201220

Received: 01 August 2018, Received in Revised Form: 30 November 2018, Accepted: 02 January 2019

\section{AUTHORS ORCID ID}

(Zaffar MALIK: 0000-0002-4343-3733), (Ghulam Hassan ABBASI: 0000-0002-0166-6264), (Sardar Alam CHEEMA: 00000001-8600-9046), (Muhammad DAWOOD: 0000-0002-8642-2735), (Muhammad Babar JAVED: 0000-0002-6453-6694), (Muhammad RAFAY: 0000-0003-2839-6986), (Malik Noman MANSHA: 0000-0002-2158-2826), (Muhammad Imran KHAN: 0000-0002-3822-6916)

\begin{abstract}
In this work, a pot experiment was conducted to evaluate the effect of organic amendments in alleviation of toxicity of untreated domestic wastewater to okra (Abelmoschus esculentus) and purslane (Portulaca oleracea). Three organic amendments including farm yard manure (FYM), poultry manure (PM) and bagasse ash (BGA) at the rate of $1 \%$ and $3 \%$ were applied to the soil to evaluate their positive impact on vegetable plants. Results showed that untreated wastewater impeded the growth of both vegetables and increased uptake of heavy metals (HMs) (i.e. $\mathrm{Cu}, \mathrm{Ni}, \mathrm{Pb}$ and $\mathrm{Zn}$ ) by plants whereas organic amendments significantly
\end{abstract}

improved the growth of plants and decreased the uptake of HMs. Shoot and root lengths and dry weights of plants were boosted by the FYM and PM, while chlorophyll $\mathrm{a}$ and $\mathrm{b}$ and carotenoids were enhanced by PM and BGA amendments. Interestingly, reduced HMs uptake was found where $3 \%$ of BGA or FYM were applied. Overall the results of this study showed that all three organic amendments were useful for improving growth of vegetables and alleviating the phytotoxicity of untreated wastewater and uptake of HMs by plants. Our findings suggest that these organic materials could be useful for improving agricultural productivity in untreated wastewater irrigated areas.

Keywords: Domestic wastewater; Farm yard manure; Poultry manure; Bagasse ash; Heavy metals

\section{Introduction}

(C) Ankara Üniversitesi Ziraat Fakültesi

Amount of wastewater produced by industrial, commercial and domestic sources has been increased significantly with increase in population growth, urbanization and industrialization to cope with the necessities of life. The wastewater is widely used to irrigate agricultural land due to scarcity of water (Zhao 
et al 2018). Both positive and negative impact has been observed for using wastewater in agriculture. Domestic wastewater contains high amount of nutrients essential for crop development compared to fresh water which might decrease the dependency on chemical fertilizers and can also reduce the discharge into water bodies (Urbano et al 2017). However, many negative impacts have been found to be associated with application of untreated wastewater such as deterioration of soil quality, reduction in crop yield, and heavy metals (HMs) pollution (Mukherjee et al 2013; Becerra-Castro et al 2015).

Many countries of the world are facing water crisis due to changing environmental condition, global warming and other associated phenomena (Rekik et al 2017). Lack of basic infrastructure to treat wastewater and water shortage have compelled under developed countries to use untreated wastewater to grow crops (Contreras et al 2017). Pakistan is also facing severe water shortage and utilization of wastewaters for irrigation is now becoming widespread practice especially in urban areas for growing vegetables. Long term irrigation of soil with untreated wastewater was reported to degrade soil quality and reduce crop yield due its toxic ingredients (Ullah et al 2012). In addition, wastewater irrigation can add non-essential potentially toxic metals such as lead $(\mathrm{Pb})$, nickel $(\mathrm{Ni})$, zinc $(\mathrm{Zn})$ and copper $(\mathrm{Cu})$ to soil and these metals remain available to plants for uptake and enhances the chances of HMs uptake and accumulation in plants, and eventually can transfer to higher trophic levels through food-chain (Singh et al 2010; Roy et al 2013; Stanojkovic-Sebic et al 2015).

Therefore, it is imperative to explore different strategies to mitigate toxic effect of untreated wastewater to crop plants. Among different options, organic amendment is considered as a most appropriate approach to minimize negative impacts of untreated wastewater on crop growth and to alleviate the toxic effects of wastewater pollutants (i.e. HMs). These amendments are easily available locally and have enormous potential for providing nutrients, improving soil structure and restricting non-essential elements in food chain. Organic muck contains significant amount of nitrogen $(\mathrm{N})$, phosphorus $(\mathrm{P})$, potassium $(\mathrm{K})$ and micronutrients which are essential for normal plant growth (Okoli \& Nweke 2015). In addition, organic manure such as farm yard manure (FYM), poultry manure (PM) and bagasse ash (BGA) are reported to have significant influences on plant growth, yield and physiological features of plants (Gebrtsadkan \& Assefa 2015; Bhushan et al 2016; Adekiya \& Agbede 2017). Heavy metals can also be sequestered in soil using organic amendments through sorption or precipitation that reduces the availability of metals for plant uptake or accumulation (Achiba et al 2016).

Studies revealed that PM has been very effective in enhancing crop growth because of its high $\mathrm{N}$ content. The role of PM in increasing crop growth and decreasing the salt stress in wheat has also been reported (Rady et al 2016). The positive impact on carrot growth by the application of PM was also reported (Sylvestre et al 2015). Similarly, the application of BGA is shown to have profound effects on crop production and is known to improve the soil water use efficiency (Bhushan et al 2016). Since organic amendments are used historically to improve the crop growth, to the best of our knowledge, their comparative effects along with the application of untreated domestic wastewater has not been investigated. In this study, a pot experiment was conducted to examine the effects of domestic untreated wastewater on different morphological and physiological features of okra (Abelmoschus esculentus) and purslane (Portulaca oleracea) crops in the presence of different soil organic amendments (i.e. FYM, PM and BGA).

\section{Material and Methods}

\subsection{Experimental setup}

A pot experiment was conducted to evaluate the effect of organic amendments in alleviation of toxicity of untreated domestic wastewater to okra and purslane. Seeds of hybrid varieties of okra and purslane were obtained from the local seed market. Soil, domestic wastewater and tap-water were collected from the farm area near Bahawalpur. The BGA was collected from Ashraf Sugar Mill on the Ahmad Pur Road, the FYM was obtained from Jafferi farm house Bahawalpur and the PM was obtained from Slamat poultry farm, Shadab Colony, Bahawalpur.

Pots were filled with $3 \mathrm{~kg}$ of the air-dried soil $(<2 \mathrm{~mm})$ along with $1 \%$ and $3 \%$ of each of different

Tarım Bilimleri Dergisi - Journal of Agricultural Sciences 26 (2020) 54-63 
amendments (i.e. BGA, FYM, and PM). Overall, there were eight treatments: T1: Tap water, T2: Domestic wastewater, T3: Domestic wastewater $+1 \%$ FYM, T4: Domestic wastewater + 3\% FYM, T5: Domestic wastewater $+1 \%$ PM, T6: Domestic wastewater $+3 \%$ PM, T7: Domestic wastewater + 1\% BGA, T8: Domestic wastewater $+3 \%$ BGA. All the treatments were applied in triplicates. The treatment pots were placed following complete randomized design. After filling the pots with soil and amendments, they were brought to the field capacity with tap water one day before sowing of okra and purslane. Both the crops were periodically irrigated with untreated wastewater.

\subsection{Water soil and plant analyses}

Domestic wastewater (DW) and tap water (TW) were collected in 2-L polythene bottles and transported immediately to the laboratory. After filtration through Whatman No. 42 filter paper, the basic physicochemical properties such as electrical conductivity (EC), soil reaction ( $\mathrm{pH})$, soluble and total phosphorous, total dissolved solids (TDS), carbonates $\left(\mathrm{CO}_{3}\right)$, bicarbonates $\left(\mathrm{HCO}_{3}\right)$, sodium $(\mathrm{Na})$, magnesium $(\mathrm{Mg})$, and calcium $(\mathrm{Ca})$ were determined according to the standard methods (APHA 1998). The filtrates were also analyzed for $\mathrm{Cu}, \mathrm{Ni}, \mathrm{Pb}$ and $\mathrm{Zn}$ using atomic absorption spectrophotometer (AAS).

For initial characterization, the soil samples were air dried, ground with pestle and mortar and sieved through $2 \mathrm{~mm}$ sieve. The soil samples were analyzed for $\mathrm{pH}, \mathrm{EC}$, exchangeable cations $(\mathrm{K}, \mathrm{Ca}, \mathrm{Mg}$ and $\mathrm{Na}$ ), $\mathrm{SO}_{4}$ and $\mathrm{Cu}, \mathrm{Ni}, \mathrm{Pb}$ and $\mathrm{Zn}$. Total nitrogen was measured by macro-Kjeldahl method (Bremner \& Mulvaney 1982) and available phosphorus was determined by Bray P1 method (Olsen \& Sommers 1982). To determine the total metals ( $\mathrm{Cu}, \mathrm{Ni}, \mathrm{Pb}$ and $\mathrm{Zn}$ ) concentrations, soil samples were digested following the Hossner method (Hossner 1996) and the concentrations of $\mathrm{Pb}, \mathrm{Cu}, \mathrm{Ni}$ and $\mathrm{Zn}$ were determined using inductively coupled plasma atomic emission spectrometry (ICP-AES). Both the AAS and ICP-AES methods were independently checked to make sure the reliability of the analytical methods.

Vegetable leaves, stem and root samples were manually harvested. All the collected samples of the vegetables were washed with distilled water to remove airborne dust. All the samples were then oven-dried in a hot air oven at $70-80^{\circ} \mathrm{C}$ for $24 \mathrm{~h}$, to remove all moisture. Dried samples were powdered using a mortar and pestle and sieved. The samples were digested using dry ash method (Hseu 2004) to determine the HMs concentration in plant parts.

\subsection{Statistical analysis}

To test the statistical significance of the mean values, one-way analysis of variance (ANOVA) was employed. After significant difference, Duncan's Multiple Range (DMR) was used for the pair wise comparisons. SAS 9.4 was used for the statistical analysis.

\section{Results}

\subsection{Physico-chemical properties of soil and domestic wastewater}

The basic physico-chemical properties of the soil and domestic wastewater are given in Table 1. Briefly,

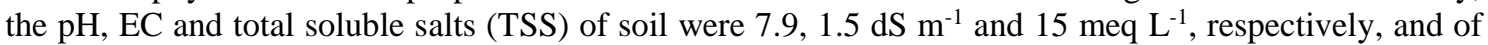
wastewater were $7.8,1.14 \mathrm{dS} \mathrm{m}^{-1}$ and 230 meq $\mathrm{L}^{-1}$, respectively.

Results showed that in general the application of domestic wastewater with soil amendments significantly improved the shoot-root length, shoot-root fresh and dry weights of okra and purslane (Figure 1). Maximum increase in the shoot length of okra and purslane was recorded in T3 (1\% FYM) and/or T5 (1\% PM) (Figure 1). Also, maximum increase in shoot fresh and dry weight of okra were recorded in T6 (3\% PM) and of purslane were recorded in T5 (1\% PM) (Figure 1).

\subsection{Growth parameters of vegetables}

Root results showed that a significant increase in the root length was found in all three treatments where 
they were applied at 3\% (T4, T6 and T8) (Figure 1). Similarly, a huge increase in the root dry weight, particularly of okra, was found where FYM and PM were applied at 3\% (Figure 1). Overall, the application of FYM and PM showed significant growth increase as compared to the control (T2).

Table 1- Physico-chemical properties of soil and untreated domestic wastewater used in this study

\begin{tabular}{lll}
\hline Parameters & Soil & Domestic wastewater \\
\hline $\mathrm{pH}$ & 7.9 & 7.8 \\
$\mathrm{EC}$ & $1.5 \mathrm{dS} \mathrm{m}^{-1}$ & $1.4 \mathrm{dS} \mathrm{m}^{-1}$ \\
TSS & $15 \mathrm{meq} \mathrm{L}^{-1}$ & $230 \mathrm{meq} \mathrm{L}^{-1}$ \\
Saturation percentage & 34 & - \\
Sulphates & $11.24 \mu \mathrm{g} \mathrm{g}^{-1}$ & - \\
Chlorides & $3.2 \mu \mathrm{g} \mathrm{g}^{-1}$ & - \\
Carbonates & - & - \\
Bicarbonates & $0.56 \mu \mathrm{g} \mathrm{g}^{-1}$ & - \\
Organic matter & $0.48 \%$ & - \\
Textural class & Loam & - \\
$\mathrm{Cu}$ & - & $0.02 \mu \mathrm{g} \mathrm{g}^{-1}$ \\
$\mathrm{Zn}$ & - & $0.05 \mu \mathrm{g} \mathrm{g}^{-1}$ \\
$\mathrm{~Pb}$ & - & $3.21 \mu \mathrm{g} \mathrm{g}^{-1}$ \\
$\mathrm{Ni}$ & - & $0.18 \mu \mathrm{g} \mathrm{g}^{-1}$ \\
$\mathrm{TDS}$ & - & $610 \mu \mathrm{g} \mathrm{g}^{-1}$ \\
$\mathrm{BOD}$ & - & $710 \mu \mathrm{g} \mathrm{g}^{-1}$ \\
$\mathrm{COD}$ & - & $989 \mu \mathrm{g} \mathrm{g}^{-1}$ \\
$\mathrm{~N}$ & $0.02 \%$ & - \\
$\mathrm{P}$ & $14.7 \mu \mathrm{g} \mathrm{g}^{-1}$ & - \\
$\mathrm{K}$ & $0.91 \%$ & - \\
\hline
\end{tabular}
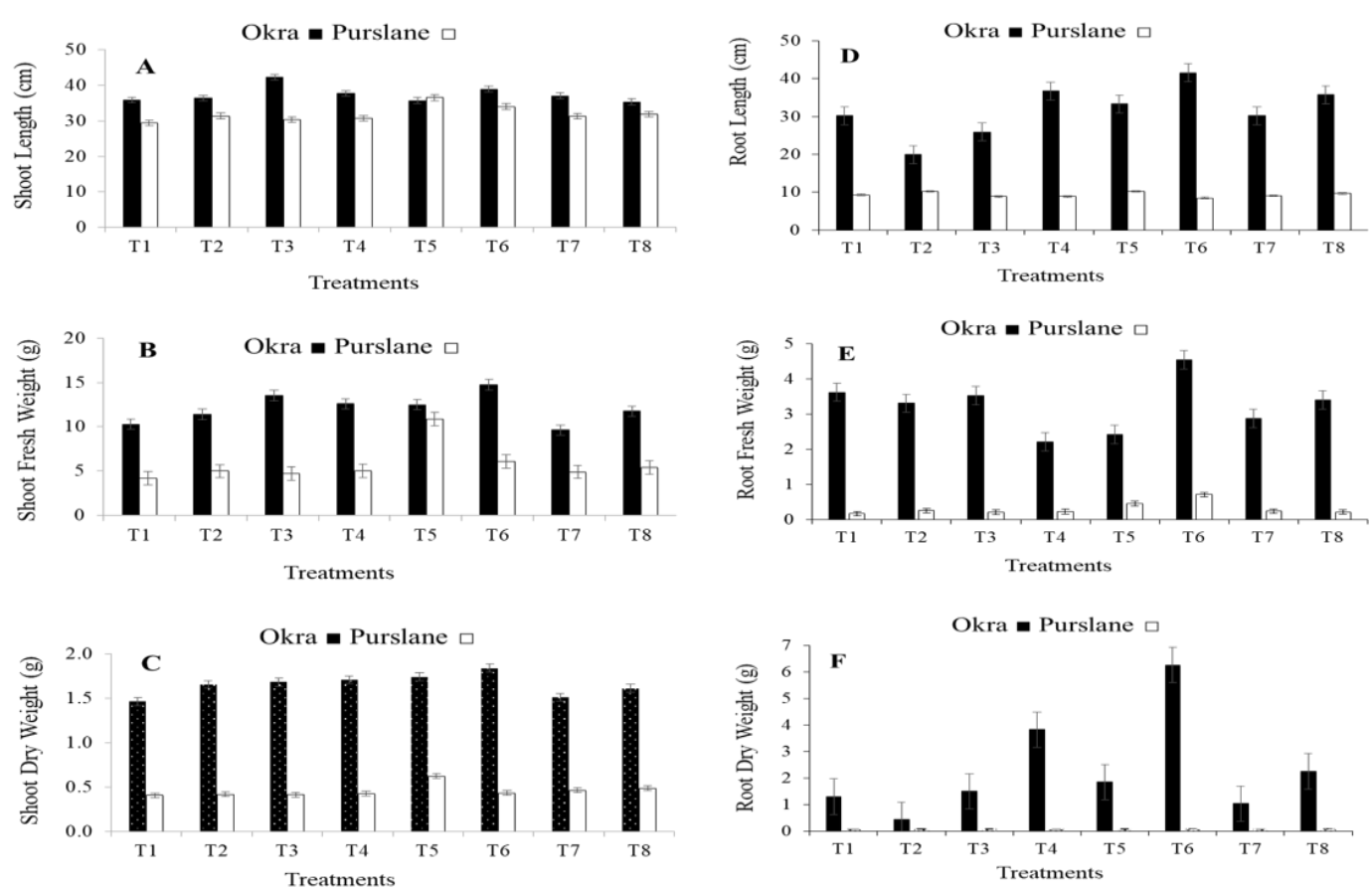

Figure 1- Effect of untreated wastewater and organic amendments on shoot length (A), shoot fresh weight $(B)$, shoot dry weight $(C)$, root length $(D)$, root fresh weight $(E)$ and root dry weight (F) of okra and purslane. Bars in the graphs show the average values of triplicate samples measured separately and error bars are the standard deviations. T1: Tap water, T2: Domestic wastewater, T3: Domestic wastewater + 1\% Farm yard manure (FYM), T4: Domestic wastewater + 3\% FYM, T5: Domestic wastewater + 1\% Poultry manure (PM), T6: Domestic wastewater + 3\% PM, T7: Domestic wastewater + 1\% Bagasse ash (BGA), T8: Domestic wastewater + 3\% BGA+ 


\subsection{Physiological parameter of vegetables}

Physiological parameters including relative water content, chlorophyll a and b, and carotenoid content of both the okra and purslane were significantly $(\mathrm{P}<0.05)$ enhanced by different levels of organic amendments applied along with the domestic wastewater. Maximum relative water contents of okra and purslane were recorded in T6 with application of 3\% PM. Chlorophyll contents were also significantly enhanced with the application of amendments. For example, maximum values of chlorophyll a in okra were found in T4 (3\% FYM) and T8 (3\% BGA), however for purslane crop, maximum values of chlorophyll a were found in T7 (1\% BGA) and T8 (3\% BGA). Maximum chlorophyll b contents of okra and purslane were found in T8 where $3 \%$ BGA was applied. Regarding carotenoid, the maximum value of both okra and purslane was recorded in T6 with application of 3\% PM (Figure 2).
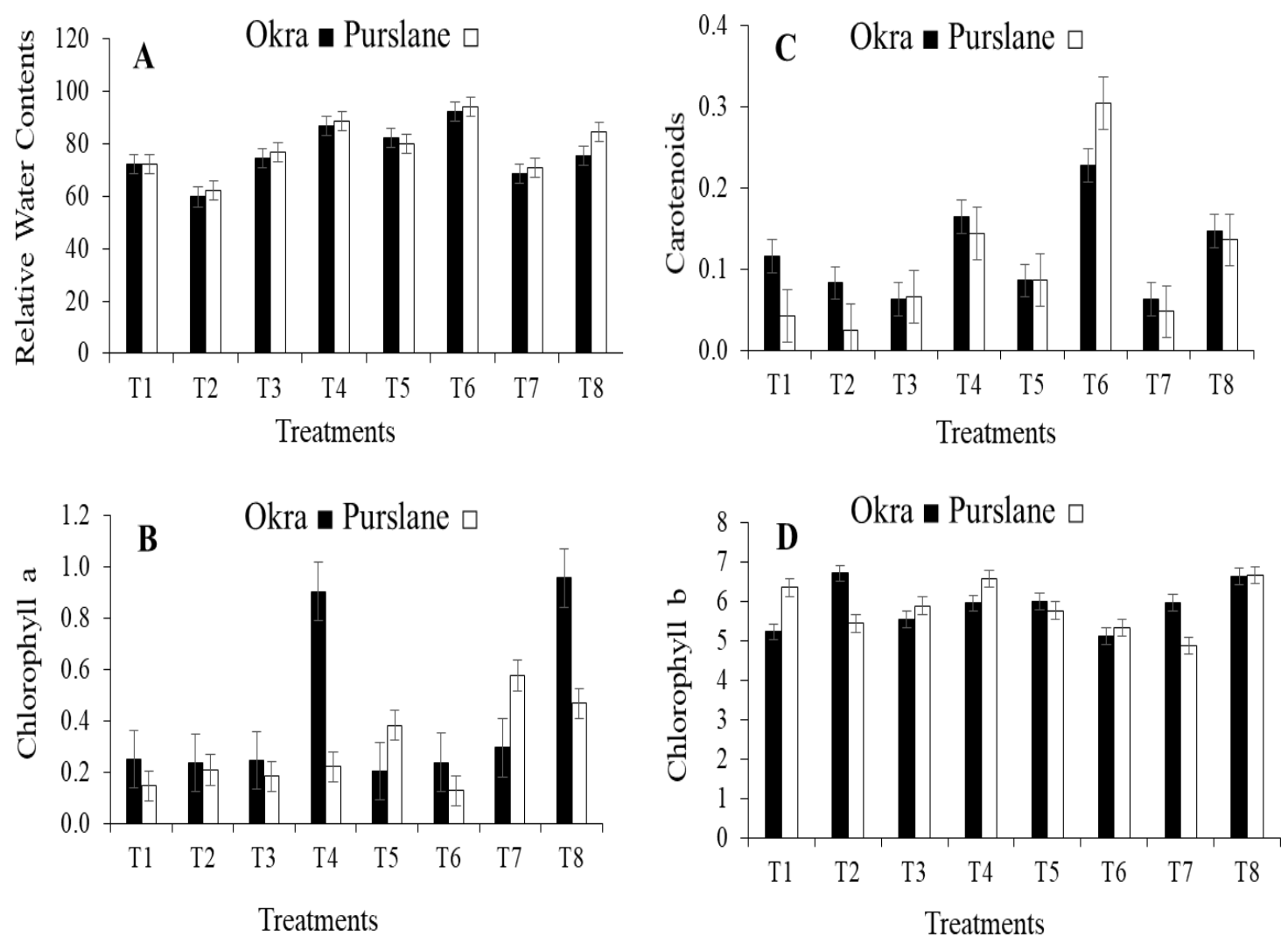

Figure 2- Effect of untreated wastewater and organic amendments on relative water content (A), carotenoid content $(C)$, chlorophyll a (B), and chlorophyll b (D) of okra and purslane. T1: Tap water, T2: Domestic wastewater, T3: Domestic wastewater + 1\% Farm yard manure (FYM), T4: Domestic wastewater + 3\% FYM, T5: Domestic wastewater + 1\% Poultry manure (PM), T6: Domestic wastewater + 3\% PM, T7: Domestic wastewater + 1\% Bagasse ash (BGA), T8: Domestic wastewater + 3\% BGA

\subsection{Heavy metal contents in vegetables}

Overall, the application of organic amendments lowers the heavy metals (HMs) uptake by both vegetables (Figure 3 and 4). Greater HMs concentrations were found in the soil, as well as in the root and shoot of plants where only the wastewater was applied (Figure 3). However, by the application of organic amendments, a significant reduction was observed in the HMs concentrations. The application of FYM and $\mathrm{PM}$ at $3 \%$ level were found to be the most effective treatments to lower the HMs uptake by okra. For purslane, the application of BGA at $3 \%$ was found to be the most promising treatment in lowering the HMs uptake. 

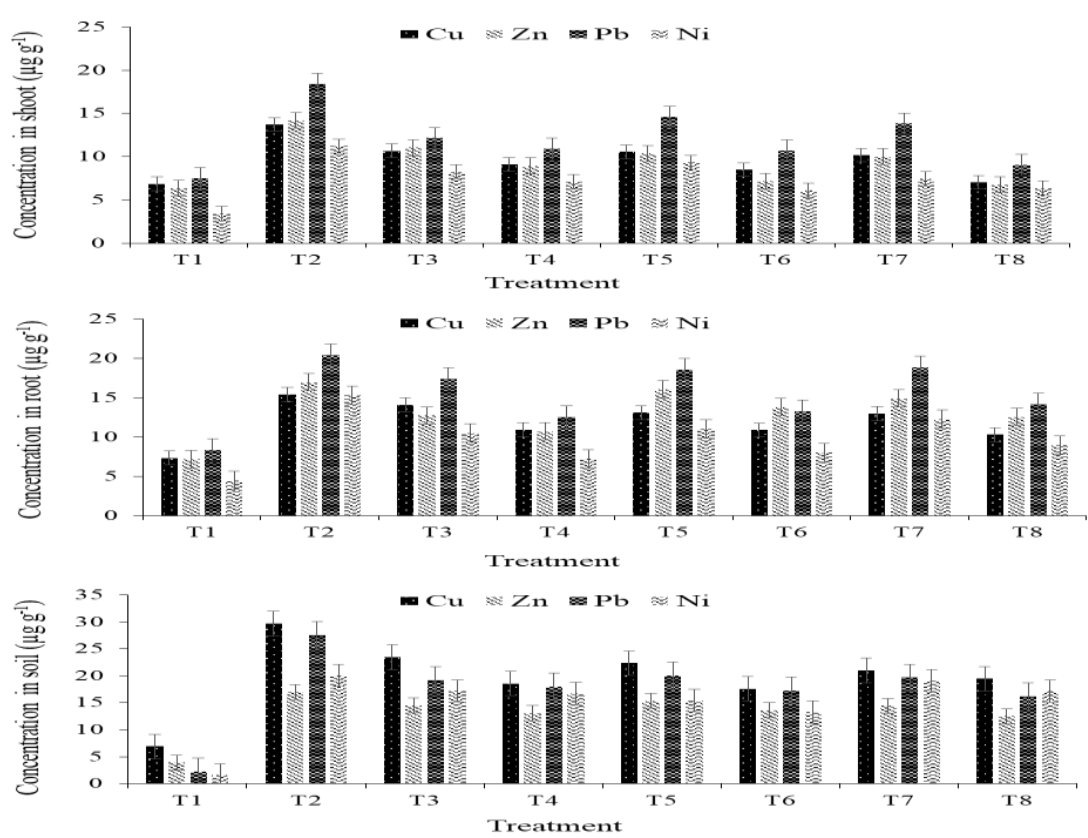

Figure 3- Effect of untreated wastewater and organic amendments on heavy metal contents in soil, root and shoot of okra. T1, Tap water; T2, Domestic wastewater; T3, Domestic wastewater $+1 \%$ Farm yard manure (FYM); T4, Domestic wastewater + 3\% FYM; T5, Domestic wastewater + 1\% Poultry manure (PM); T6, Domestic wastewater + 3\% PM; T7, Domestic wastewater + 1\% Bagasse ash (BGA); T8, Domestic wastewater + 3\% BGA
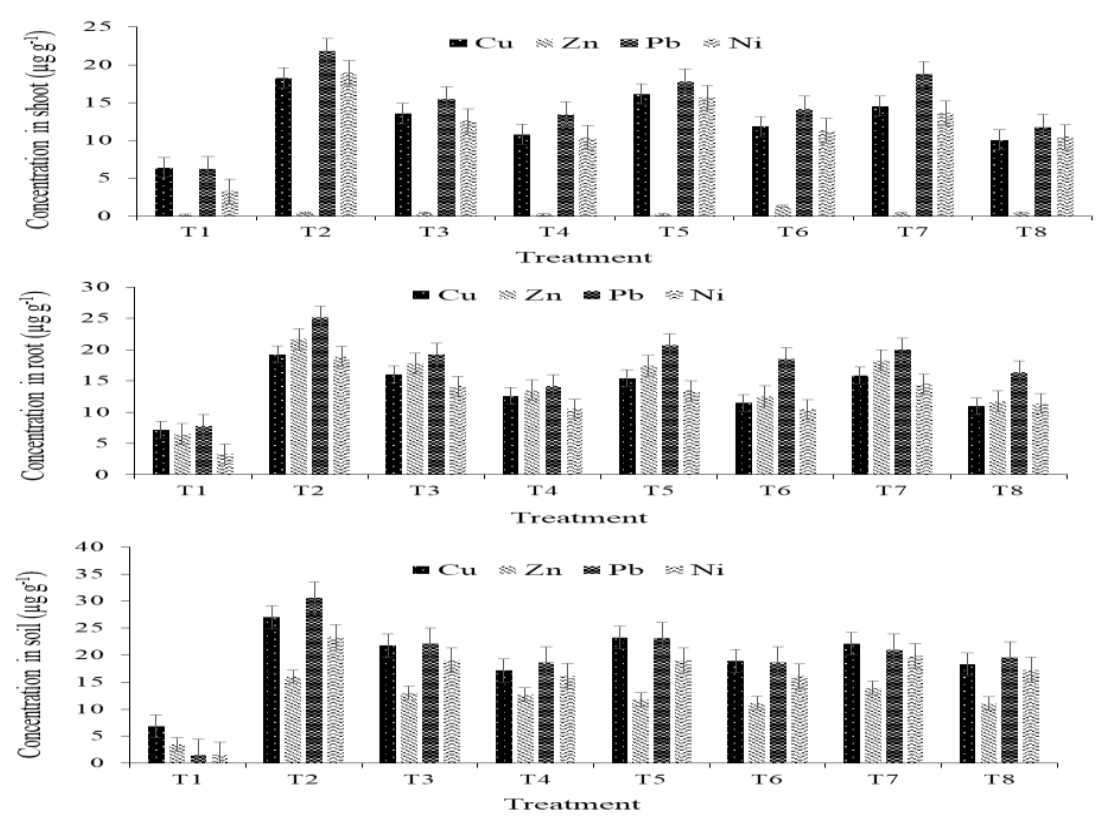

Figure 4- Effect of untreated wastewater and organic amendments on heavy metal contents in soil, root and shoot of purslane. T1, Tap water; T2, Domestic wastewater; T3, Domestic wastewater $+1 \%$ Farm yard manure (FYM); T4, Domestic wastewater + 3\% FYM; T5, Domestic wastewater + 1\% Poultry manure (PM); T6, Domestic wastewater + 3\% PM; T7, Domestic wastewater + 1\% Bagasse ash (BGA); T8, Domestic wastewater + 3\% BGA 


\section{Discussion}

The scarcity of freshwater and ever-increasing demand of irrigation water compel the farming community to use untreated wastewater particularly in the developing countries, to irrigate crops. Although reuse of wastewater is considered beneficial for environmental and economic view point, there are serious agricultural and health risks associated with this application: soil salinity, pathogenicity, reduced crop development and HMs contamination is one of the serious concerns (Contreras et al 2017; Urbano et al 2017).

In the current study, results of physiological features such as relative water contents, carotenoids and chlorophyll $\mathrm{a}$ and $\mathrm{b}$ of okra and purslane showed that they were drastically affected and reduced 5-20\% by the application of untreated domestic wastewater as compared to the control (i.e. Tap water) (Figure 2). The probable reason of lowering the water content could be the reduction of the photosynthetic rate and $\mathrm{CO}_{2}$ assimilation in the plants. Several studies indicated that high chemical stress (EC, BOD, COD and HMs) in untreated wastewater inhibits metabolic mechanism by disrupting photosynthesis, transpiration rate and stomatal conductance ultimately leading to growth inhibition (Abegunrin et al 2016; Akhkha et al 2017). Another reason for poor physiological features and growth inhibition of vegetables obtained in this study (Figure 1) could be due to the presence of toxic HMs in the untreated wastewater. HMs present in the soil are not phytoavailable due to poor solubility, however, HMs entry through anthropogenic means (domestic wastewater) increase their mobility in soil and pose threat to biota. This exogenous application of HMs, present in the wastewater, was able to inhibit the growth of both crops. Notably, high concentrations of $\mathrm{HMs}(\mathrm{Cu}, \mathrm{Ni}, \mathrm{Pb}$ and $\mathrm{Zn})$ in soil as well as in plant parts (okra and purslane) were found after untreated wastewater application.

Low relative water contents (i.e 10\% lower than that of organic amended treatment) observed in plants without any soil organic amendment, could be due to the HMs toxicity. Numerous studies found similar results that HMs toxicity significantly decreases the water content in the crops. For instance, Pb toxicity was found to decrease amount of water in Brassica juncea (Zaier et al 2010). Inhibition of plant growth, particularly the root length, was reported by the excessive accumulation of $\mathrm{Zn}$ (Wang et al 2009). Excessive $\mathrm{Cu}$ in maize was reported to reduce the root length and plant height along with the substantial decrease in the overall plant growth (Ali et al 2002).

Interestingly, our results showed that the application of organic amendments significantly improved the physiological parameters and growth of both vegetables. Specifically, FYM and PM produced high carotenoids contents, while FYM and BGA produced more chlorophyll contents indicating that FYM was a better amendment as compared to PM or BGA to physiologically improve the growth of vegetable crops. Additionally, the application of organic amendments (i.e. FYM, PM and BGA) enhanced the immobilization of HMs and thus, did not allow them to transfer to the above ground biomass. Organic amendments through immobilization of HMs alleviated their phytotoxic effects and ultimately boosted the growth of plants (Figure 1). In general, FYM or PM applied at 3\% level was found to be effective in enhancing the growth of both vegetables. Our results are in agreement with those of Meeinkuirt et al (2016), who reported that the growth of plants was significantly increased by the application of organic amendments on $\mathrm{Cd}$ contaminated soils.

Furthermore, uptake and accumulation of HMs in different plant parts were significantly reduced in the presence of organic amendments. This accumulation of HMs was 5-30\% lower than that of control (i.e. without organic amendment). Results of several studies support our findings where organic amendments were reported to decrease uptake and accumulation of HMs in different plant parts (Daniela et al 2015; Rady et al 2016; Meeinkuirt et al 2016). Likewise, FYM was observed more beneficial in lowering HMs uptake by plants (Rehman et al 2016; Achiba et al 2016). Although on different plant, the application of FYM and PM had previously been proven to improve the physiological parameters of bitter gourd (Momordica charantia L.) (Haq et al 2015). The possible explanation for this could be that organic amendments are rich sources of organic matter (OM) which on decomposition not only provides nutrients for plant growth but also reduces mobility and bioavailability of HMs in soil by complexation with humic substances to form organo-metal complexes (Moreno-Jiménez et al 2017). High OM contents in FYM and 
PM could enhance plant growth by increasing biological activity, macro-nutrients, CEC and buffering capacity in soil (Paulose et al 2007). Another plausible reason for restricted entry of HMs to plant might be the $\mathrm{pH}$ as organic amendments increase soil $\mathrm{pH}$ which in turn decrease metals mobility in soil (Walker et al 2004; Moreno-Jiménez et al 2017).

BGA used as an absorbent for HMs in soil is another cost-effective technique reported in many studies. BGA has tremendous capacity for absorption of $\mathrm{HMs}(\mathrm{Ni}, \mathrm{Cu}, \mathrm{Zn}, \mathrm{Pb}$ and $\mathrm{Cd}$ ) and this capacity could increase with increasing soil $\mathrm{pH}$ ( $\mathrm{Yu}$ et al 2013; Malik et al 2017). Many functional groups such as hydroxyl, carbonyl and amine were reported to be involved in metal binding in cellulose rich material which could be used to treat wastewater (Noor et al 2017; Bhat et al 2017). In short, our findings suggest that organic amendments have potential not only to reduce toxic effects of untreated wastewater pollutants (i.e. $\mathrm{HMs}$ ) but also provide nutrients for plant growth.

\section{Conclusions}

Application of organic amendments (i.e. FYM, PM, and BGA) greatly enhanced the growth of okra and purslane irrigated with untreated wastewater. Our findings suggest that application of soil organic amendments could greatly reduce the phytotoxicity of untreated wastewater. Our study results can be used to forecast adverse effects of chemical stresses (especially due to HMs) on other vegetables irrigated with industrial, commercial and other types of untreated wastewater. In addition, the results of the current study have important implications on the use of organic amendments for attenuation of HMs from contaminated soil and improving agricultural productivity in untreated wastewater irrigated areas.

\section{References}

Abegunrin T P, Awe G O, Idowu D O \& Adejumobi M A (2016). Impact of wastewater irrigation on soil physicochemical properties, growth and water use pattern of two indigenous vegetables in southwest Nigeria. Catena 139: $167-178$

Achiba W B, Gabteni N, Laing G D, Verloo M, Jedidi N \& Tahar G (2016). Heavy metal availability and uptake by wheat crops cultivated in Tunisian field plots amended during five years with municipal solid waste compost and farmyard manure. Journal of Research in Environmental and Earth Sciences 4: 146-154

Adekiya A O \& Agbede T M (2017). Effect of methods and time of poultry manure application on soil and leaf nutrient concentrations, growth and fruit yield of tomato (Lycopersicon esculentum Mill). Journal of the Saudi Society of Agricultural Sciences 16(4): 383-388

Akhkha A, Boutraa T \& Al-Shoaibi A K (2017). The influence of al-Madinah al-Munawwara treated and untreated domestic wastewater on growth and physiology of three tomato (Lycopersicon esculentum Mill.) genotypes. Pakistan Journal of Botany 49(3): 879-890

Ali N A, Bernal M P \& Ater M (2002). Tolerance and bioaccumulation of copper in Phragmites australis and Zea mays. Plant and Soil 239(1): 103-111

APHA (1998). Standard methods for examination of water and wastewater. American Public Health Association, Washington, DC, USA

Becerra-Castro C, Lopes A R, Vaz-Moreira I, Silva E F, Manaia C M \& Nunes O C (2015). Wastewater reuse in irrigation: A microbiological perspective on implications in soil fertility and human and environmental health. Environment International 75: 117-135

Bhat S A, Singh J \& Vig A P (2017). Amelioration and degradation of pressmud and bagasse wastes using vermitechnology. Bioresource Technology 243: 1097-1104

Bhushan G, Kumar S, Dwivedi S \& Sharma S K (2016). Impact of bagasse ash amended Soil on growth and yield of Pisum sativum. Research Journal of Pharmaceutical Biological and Chemical Sciences 7(1): 448-556

Bremner J M \& Mulvaney C S (1982). Nitrogen -Total. In: Methods of soil analysis. Madison, WI: American Society of Agronomy, pp. 295-324

Tarım Bilimleri Dergisi - Journal of Agricultural Sciences 26 (2020) 54-63 
Contreras J D, Meza R, Siebe C, Rodríguez-Dozal S, López-Vidal Y A, Castillo-Rojas G \& Vázquez-Salvador N (2017). Health risks from exposure to untreated wastewater used for irrigation in the Mezquital Valley, Mexico: A 25-year update. Water Research 123: 834-850

Daniela K, Jakub E \& Lukas P (2015). Effect of compost amendment on heavy metals transport to plant. Mendel Net 249-254

Gebrtsadkan G \& Assefa D (2015. Evaluating the effect of integrated use of farm yard manure and urea on the socio economic performance of Tomato (Lycopersicon esculentum Mill) at Tselemti Woreda, North western Tigray, Ethiopia. Journal of Biology, Agriculture and Healthcare 5(9): 158-164

Haq M A, Ahmad N, Farooq U, Zafar H \& Ali M A (2015). Effect of different organic materials and chemical fertilizer on yield and quality of bitter gourd (Momordica charantia L.). Soil \& Environment 34(2): 142-147

Hossner L R (1996). Dissolution for total elemental analysis. Methods of soil analysis part 3-Chemical Methods pp. 49-64

Hseu Z Y (2004). Evaluating heavy metal contents in nine composts using four digestion methods. Bioresource Technology 95: 53-59

Malik D S, Jain C K \& Yadav A K (2017). Removal of heavy metals from emerging cellulosic low-cost adsorbents: A review. Applied Water Science 7(5): 2113-2136

Meeinkuirt W, Kruatrachue M, Pichtel J, Phusantisampan T \& Saengwilai P (2016). Influence of organic amendments on phytostabilization of Cd-contaminated soil by Eucalyptus camaldulensis. Science Asia 42(2): 83-91

Moreno-Jiménez E, Sepúlveda R, Esteban E \& Beesley L (2017). Efficiency of organic and mineral based amendments to reduce metal [loid] mobility and uptake (Lolium perenne) from a pyrite-waste contaminated soil. Journal of Geochemical Exploration 174: 46-52

Mukherjee V, Das A, Akhand A \& Gupta G (2013). Toxicity and profitability of rice cultivation under wastewater irrigation: The case of the East Calcutta Wetlands. Ecological Economics 93: 292-300

Noor N M, Othman R, Mubarak N M \& Abdullah E C (2017). Agricultural biomass-derived magnetic adsorbents: Preparation and application for heavy metals removal. Journal of the Taiwan Institute of Chemical Engineers 78 : $168-177$

Okoli P S O \& Nweke I A (2015). Effect of poultry manure and mineral fertilizer on the growth performance and quality of cucumber fruits". Journal of Experimental Biology and Agricultural Sciences 3(4): 362-367

Olsen S R \& Sommers L E (1982). Phosphorus $2^{\text {nd }}$ ed. In: Methods of Soil Analysis. Agronomy Monograph No. 9. Madison, WI. American Society of Agronomy, pp. 403-430

Paulose B, Datta S P, Rattan R K \& Chhonkar P K (2007). Effect of amendments on the extractability, retention and plant uptake of metals on a sewage-irrigated soil. Environmental Pollution 146(1): 19-24

Rady M M, Mounzer O, Alarcón J, Abdelhamid M \& Howladar S (2016). Growth, heavy metal status and yield of saltstressed wheat (Triticum aestivum L.) plants as affected by the integrated application of bio-, organic and inorganic nitrogen-fertilizers. Journal of Applied Botany and Food Quality 89: 21-28

Rehman M Z U, Rizwan M, Ali S, Fatima N, Yousaf B, Naeem A \& Ok Y S (2016). Contrasting effects of biochar, compost and farm manure on alleviation of nickel toxicity in maize (Zea mays L.) in relation to plant growth, photosynthesis and metal uptake. Ecotoxicology and Environmental Safety 133: 218-225

Rekik I, Chaabane Z, Missaoui A, Bouket A C, Luptakova L, Elleuch A \& Belbahri L (2017). Effects of untreated and treated wastewater at the morphological, physiological and biochemical levels on seed germination and development of sorghum (Sorghum bicolor (L.) Moench), alfalfa (Medicago sativa L.) and fescue (Festuca arundinacea Schreb.). Journal of Hazardous Materials 326: 165-176

Roy S, Banna L N, Mamun S A \& Farukh M A (2013). Effects of industrial wastewater reuse for crop production: A case study in Tejgaon metropolitan area of Dhaka, Bangladesh. Journal of the Bangladesh Agricultural University 11(2): $183-188$ 
Singh A, Sharma R K, Agrawal M \& Marshall F M (2010). Health risk assessment of heavy metals via dietary intake of foodstuffs from the wastewater irrigated site of a dry tropical area of India. Food and Chemical Toxicology 48(2): 611-619

Stanojkovic-Sebic A, Pivic R, Josic D, Dinic Z \& Stanojkovic A (2015). Heavy metals content in selected medicinal plants commonly used as components for herbal formulations. Journal of Agricultural Sciences 21: 317-325

Sylvestre H, Constance M, Esdras N \& Athanase N (2015). Effect of poultry manure and NPK (17-17-17) on growth and yield of carrot in Rulindo District, Rwanda. International Journal of Novel Research in Life Sciences 2: 42-48

Ullah H, Khan I \& Ullah I (2012). Impact of sewage contaminated water on soil, vegetables, and underground water of peri-urban Peshawar, Pakistan. Environmental Monitoring and Assessment 184: 6411-6421

Urbano V R, Mendonça T G, Bastos R G \& Souza C F (2017). Effects of treated wastewater irrigation on soil properties and lettuce yield. Agricultural Water Management 181: 108-115

Walker D J, Clemente R \& Bernal M P (2004). Contrasting effects of manure and compost on soil pH, heavy metal availability and growth of Chenopodium album L. in a soil contaminated by pyritic mine waste. Chemosphere 57: $215-224$

Wang C, Zhang S H, Wang P F, Hou J, Zhang W J, Li W \& Lin Z P (2009). The effect of excess Zn on mineral nutrition and antioxidative response in rapeseed seedlings. Chemosphere 75: 1468-1476

Yu J X, Wang L Y, Chi R A, Zhang Y F, Xu Z G \& Guo J (2013). Adsorption of Pb ${ }^{2+}$, $\mathrm{Cd}^{2+}$ and $\mathrm{Zn}^{2+}$ from aqueous solution by modified sugarcane bagasse. Research on Chemical Intermediates 41: 1525-1541

Zaier H, Mudarra A, Kutscher D, de la Campa M R F, Abdelly C \& Sanz-Medel A (2010). Induced lead binding phytochelatins in Brassica juncea and Sesuvium portulacastrum investigated by orthogonal chromatography inductively coupled plasma-mass spectrometry and matrix assisted laser desorption ionization-time of flight-mass spectrometry. Analytica Chimica Acta 671: 48-54

Zhao L, Xie J, Zhang H, Wang Z, Jiang H \& Gao S (2018). Enzymatic activity and chlorophyll fluorescence imaging of maize seedlings (Zea mays L.) after exposure to low doses of chlorsulfuron and cadmium. Journal of Integrative Agriculture 17(4): 826-836 